\section{Editorial: A Plea for Ethical \\ Autonomy as a Transdisciplinary Social Science}

\section{Antonio SANDU ${ }^{1}$, Ana FRUNZĂ ${ }^{2}$}

${ }^{1}$ Professor PhD Hab., Ştefan cel Mare University from Suceava, România; University of Oradea, Romania, antonio1907@yahoo.com.

${ }^{2} \mathrm{PhD}$ Researcher, LUMEN

Research Center in Social and Humanistic Sciences, Iasi, Romania \& Associated Assistant PhD, Stefan cel Mare University from Suceava, Romania, ana.caras.15@yahoo.com

\begin{abstract}
The approach of ethics from the perspective of epistemic autonomy comes to bring together the professional concerned with the ethical reflection on his own practice and his own epistemological, ethical and ethical horizon, with those of the professional ethic who are addressing the ethical significance of practice in the various fields of social research, no more. This editorial proposes a number of directions of interest in the field of ethics in social science research, as the preferred domains, without being exclusive to the on-going Journal of Ethics in Social Studies.
\end{abstract}

Keywords: Professionalization of ethics, applied ethics, ethics of research in social sciences.

How to cite: Sandu, A., \& Frunza, A. (2017). Editorial: A Plea for Ethical Autonomy as a Transdisciplinary Social Science. Journal for Ethics in Social Studies, 1(1), 1-6.

https://doi.org/10.18662/iess/01 


\section{Introducere}

Componenta etică a cercetării sociale a căpătat o importanţă din ce în ce mai mare în ultimii ani, reflecția etică fiind parte integrantă din orice proiect de cercetare. Editorialul de faţă propune o serie de direcții de interes în domeniul eticii din cercetarea din ştiințele sociale, ca domenii predilecte, fără a fi exclusive pentru Journal of Ethics in Social Studies, aflat la debut.

\section{Scurtă pledoarie pentru autonomizarea eticii în calitate de ştiință socială transdisciplinară}

Dacă în sfera cercetărilor biomedicale etica îşi are un loc bine stabilit, cercetătorii înțelegând necesitatea ca reflecția etică să însoțească la modul afirmativ fiecare demers de cercetare - în sensul deschiderii orizontului cercetării şi nu doar al limitării misconduct -, în ştiinţele sociale etica este privită de mulți cercetători şi universitari într-o manieră limitativă, rolul acesteia limitându-se de multe ori la prevenția şi evitarea plagiatului, reprimarea tendințelor de fabricare a datelor, etc.

Teme precum protecția subiecților cercetării, standarde etice în publicarea rezultatelor cercetării specifice ştiințelor sociale, corecta definire a autoratului în cercetările sociale - de exemplu a celor de tipul participator, research, pot contribui la creșterea unei etici afirmative a cercetării în ştiințele sociale.

Analiza riscurilor implicate de cercetarea socială poate fi uneori la fel de semnificativă ca şi a celor din sfera biomedicală. Putem da ca exemplu cercetările vizând capacitatea de manipulare seductivă pe care mass-media tradițională, dar mai ales noile media, o zonă de cercetare a ştiintelor comunicării, o poate avea asupra diferitelor categorii de public. În aceeaşi zonă a evaluării riscurilor putem include reflecția etică şi metaetică asupra cercetărilor din sfera Big Data, în conjuncție cu redefinirea sferei private şi a celei publice într-o societate a supravegherii extinse şi a sistemelor expert care au acces la urmele noastre digitale. Capacitatea de a influența opinii politice, sociale sau economice, prin intermediul publicității dirijate, ce are până la urmă la bază o cercetare a comportamentului social al indivizilor, invocă, în opinia noastră, nevoia unei reflecții etice asupra dezvoltării sociale, însăşi în conjuncție cu dezvoltarea eticii cercetării sociale.

Este rolul cercetării sociale să integreze etica nu doar ca o reflecţie asupra limitelor propriilor demersuri, ci să o dezvolte la nivelul unei ştiinte sociale transdisciplinare care să se preocupe de evaluarea capacității destructive versus a beneficităţii practicilor sociale, dar şi a diverselor 
tehnologii - nu doar a celor biomedicale, dar mai ales a celor comunicaționale, în măsură la ora actuală de a duce umanitatea în pragul unei singularități antropologice prin virtualizarea spațiului social. Perspectiva unei mutaţii radicale nu doar în existent, dar şi devenirea specie umane, ar trebui să preocupe cercetătorii din sfera socialului în reală măsură, ca pe eticienii teoretici, bioeticieni sau eticienii specializați în evaluarea tehnologiilor cum ar fi biologia sintetică, modificările genetice, comunicarea om-maşină, prelungirea vieții, etc.

In sfera de interes a eticii studiilor sociale s-ar putea integra teme precum: dimensiuni etice ale cercetării şi inovării, proprietatea asupra datelor rezultate din investigații sociale, proiectarea etică a unei cercetări sociale, sau care afectează spațiul social, valoarea etică a cunoaşterii privită ca sursă de putere dar şi de posibile inechităţi în dezvoltare, responsabilitatea cercetătorului şi a instituției de cercetare în societatea cunoaşterii şi limitele cunoaşterii responsabile, riscuri etice ale cercetării sociale în calitate de cercetare pe subiecți umani, particularități ale protecției subiecților în cercetările cantitative si calitative, dreptul la identitate şi privacy, dreptul la confidențialitate versus obligația de a informa societatea asupra potențialelor riscuri, consimțământ informat, strategii de obţinere şi tipuri de consimțământ informat, funcționarea comisiilor de etică, aprobarea etică a cercetării, etica publicării, plagiat şi strategii de combatere a plagiatului, fabricarea datelor în ştiinţele sociale, greşeli de eşantionare şi efecte asupra validităţii rezultatelor, ghost writing, cine este îndreptăţit să fie autor în cercetările sociale, open acces publication, etică în procesul de peer review, retragerea de la publicare şi retractarea, etc

Abordarea eticii din perspectiva unei autonomizări epistemice vine să reunească profesionistul preocupat de reflecția etică asupra propriei practici şi a propriului orizont epistemic - axiologic şi etic, cu cele ale eticianului profesionist care se apleacă asupra semnificaţiilor etice, ale practicii din diversele domenii ale cercetării sociale, şi nu numai. Inginerul care proiectează o tehnologie comunicațională, care are potențial de a schimba însăşi percepția asupra realităţii (tehnologiile realităţii virtuale sau augmentate), poate avea opinii, inclusiv o reflecție etică asupra posibilelor efecte sociale ale tehnologiei, numai un etician profesionalizat ca cercetător al spațiului social şi al efectelor pe care cercetarea, fie ea teoretică, aplicată sau tehnologică, o are asupra socialului la nivel global sau local.

\section{În loc de concluzii}

Susținem profesionalizarea eticii aplicate în diferitele sale componente, în conjuncție cu autonomizarea unei ştiinte a eticii în sfera 
ştiințelor sociale, cu o largă perspectivă transdisciplinară, la intersecție cu filosofia, sociologia, dreptul, ştiințele comunicării, bioetica, precum şi eticile şi deontologiile particulare diferitelor arii de cercetare şi inovare, cu potențial influent asupra evoluției societății la orice nivel al său.

\section{Introduction}

The ethical component of social research has become more and more important in recent years, with ethical reflection being an integral part of any research project. This editorial proposes a series of directions of interest in social science research ethics, as preferred domains, without being exclusive to the onset of the Journal of Ethics in Social Studies.

\section{Short advocacy for ethical autonomy as a transdisciplinary social science}

If ethics in the field of biomedical research has a well-established place, researchers understanding the need for ethical reflection to affirmatively accompany each research approach - in the sense of opening the research horizon rather than limiting the misconduct - in social ethics is regarded by many researchers and academics in a limiting manner, its role being often limited to preventing and avoiding plagiarism, suppressing data production trends, etc.

Issues such as the protection of research subjects, ethical standards in the publication of research results specific to social sciences, the correct definition of authorship in social research - eg participatory, research, may contribute to the development of an affirmative ethics of research in social sciences.

Analysis of the risks involved in social research can sometimes be as significant as those in the biomedical sphere. We can, for example, investigate the capacity for seductive manipulation that traditional media, but especially the new media, a research area of communication sciences, can have on different audiences. In the same area of risk assessment we can include ethical and methetical reflection on Big Data research, in conjunction with redefining the private and public spheres in a broad-based surveillance society and expert systems that have access to our digital footprints. The ability to influence political, social or economic views through guided advertising, which ultimately has the basis of research into the social behavior of individuals, invokes in our opinion the need for an 
ethical reflection on social development, in conjunction with the development of ethics of social research.

It is the role of social research to integrate ethics not only as a reflection on the limits of their own approaches, but to develop it at the level of a transdisciplinary social science that is concerned with the assessment of destructive capacity versus the benefit of social practices, but also of various technologies - of the biomedical, but especially of the communication ones, able to lead humanity to the point of anthropological singularity through virtualization of the social space.

The prospect of a radical mutation not only in existence, but also of becoming a human species, should really concern social scientists like theoreticians, bioethics or ethics specialists in the assessment of technologies such as synthetic biology, genetic modification, human communication machine, prolongation of life, etc.

In the sphere of interest of ethics of social studies one could integrate themes such as: ethical dimensions of research and innovation, ownership of social investigation data, ethical design of social research, or affecting the social space, the ethical value of knowledge seen as a source of power but also potential development inequities, the responsibility of the researcher and research institution in the knowledge society and the limits of responsible knowledge, ethical risks of social research as research on human subjects, particularities of the protection of subjects in quantitative and qualitative research, the right to identity and privacy, the right to confidentiality versus the obligation to inform the society about potential risks, informed consent, acquisition strategies and informed consent, the functioning of ethics committees, ethical approval of research, public ethics plagiarism and strategies to combat plagiarism, data production in social sciences, sampling errors and effects on the validity of results, ghost writing, who is entitled to be author in social research, open access publication, peer review ethics, withdrawal from publication and retraction, etc

The approach of ethics from the perspective of epistemic autonomy is to bring together the professional concerned with the ethical reflection on his own practice and his own epistemic - axiological and ethical horizon, with those of the professional ethic who is addressing the ethical significance of practice in various fields of social research, and not only. The engineer who designs a communication technology that has the potential to change the perception of reality (virtual or augmented reality technologies) may have views, including an ethical reflection on the possible social effects of technology, only a professional ethician as a researcher of the social space 
and of the effects that research, either theoretical, applied or technological, has on society, globally or locally.

\section{Instead of conclusions}

We support the professionalization of ethics applied in its various components, in conjunction with the autonomy of a science of ethics in the sphere of social sciences, with a broad transdisciplinary perspective, intersecting with philosophy, sociology, law, communication sciences, bioethics, as well as the particular ethics and deontologies of different areas of research and innovation, with potential influence on the evolution of society at any level.

\section{Acknowledgment}

The article was developed within the Programme „Etică şi integritate academică de excepție în cercetarea ştiințifică şi actul didactic”, implementer: Stefan cel Mare University from Suceava, with financial support from FDI2018, Domeniul 5, Îmbunătățirea calității activității didactice, inclusiv a respectării deontologiei şi eticii academice. Project code: CNFIS-FDI-2018-0545. 